\title{
The Latin-American Union and the LAT
}

\author{
Luis F. Copertari \\ Computer Engineering Program, \\ Autonomous University of Zacatecas (UAZ), \\ Zacatecas, México.
}

\begin{abstract}
Objective. To support the creation of a Latin-American Union with the creation of the Latin-American peso (LAT) as the common currency. Methodology. Analysis and synthesis using induction and deduction proposing theory and reviewing its validity. Results. The LAT can be used as a robust enough currency. Limitations. The study was carried out only for the three main Latin-American Union candidates: Argentina, Brazil and Mexico. Originality. The ideas proposed here are original in the way the LAT is meant to function. Conclusions. The LAT promises to be a good option for stabilizing Latin-America and promote its regional development.
\end{abstract}

Keywords: Latin-American Union; LAT; money; system.

\section{INTRODUCTION}

The Latin-American Peso (or simply LAT) is the common currency proposed for the creation of a Latin-American Union. Clearly, it is very important that the LAT works correctly. This paper aims to devise and theoretically test the functioning of the LAT in such Latin-American Union.

The idea of a Latin-American Union is not new (Arana, 2013; Bushnell, 1970; Harvey, 2000; Crow, 1980; Holden \& Zolov, 2000). The Latin-American Union proposed here includes twenty sovereign national states in Latin America. Latin America includes all countries south of the United States with Latin as the basic common root of their respective languages. Hence, the term Latin America. Table 1 shows all twenty candidate Latin-American countries. In order to be a candidate Latin-American country, it is required: 1) To be part of Latin America, 2) To be a sovereign national state, and 3) To share the common Latin root in its official language. 
Table 1. Relevant information of all 20 sovereign Latin American countries.

\begin{tabular}{|c|c|c|c|c|c|c|}
\hline $\begin{array}{l}\text { No. } \\
(\mathrm{k})\end{array}$ & Flag & Name & Area $\left(\mathrm{km}^{2}\right)$ & $\begin{array}{l}\text { Population } \\
(2016)\end{array}$ & $\begin{array}{l}\text { Population } \\
\text { Density }\end{array}$ & Capital \\
\hline 1 & $=$ & Argentina & $2,780,400$ & $43,847,430$ & 14.40 & Buenos Aires \\
\hline 2 & 들 & Bolivia & $1,098,581$ & $10,887,882$ & 9.00 & Sucre and La Paz \\
\hline 3 & $\theta$ & Brazil & $8,515,767$ & $207,652,865$ & 23.60 & Brasília \\
\hline 4 & "- & Chile & 756,096 & $17,909,754$ & 23.00 & Santiago \\
\hline 5 & - & Colombia & $1,141,748$ & $48,653,419$ & 41.50 & Bogotá \\
\hline 6 & & Costa Rica & 51,100 & $4,857,274$ & 91.30 & San José \\
\hline 7 & $\equiv$ & $\begin{array}{l}\text { Cuba } \\
\text { Dominican }\end{array}$ & 109,884 & $11,475,982$ & 100.60 & Havana \\
\hline 8 & & Republic & 48,442 & $10,648,791$ & 210.90 & Santo Domingo \\
\hline 9 & ت & Ecuador & 283,560 & $16,385,068$ & 54.40 & Quito \\
\hline 10 & & El Salvador & 21,040 & $6,344,722$ & 290.30 & San Salvador \\
\hline 11 & & Guatemala & 108,889 & $16,582,469$ & 129.00 & Guatemala City \\
\hline 12 & & Haiti & 27,750 & $10,847,334$ & 350.00 & Port-au-Prince \\
\hline 13 & & Honduras & 112,492 & $9,112,867$ & 76.00 & Tegucigalpa \\
\hline 14 & & Mexico & $1,964,375$ & $127,540,423$ & 57.00 & Mexico City \\
\hline 15 & & Nicaragua & 130,375 & $6,149,928$ & 44.30 & Managua \\
\hline 16 & ب & Panama & 75,517 & $4,034,119$ & 54.20 & Panama City \\
\hline 17 & & Paraguay & 406,752 & $6,725,308$ & 14.20 & Asunción \\
\hline 18 & & Peru & $1,285,216$ & $31,773,839$ & 23.00 & Lima \\
\hline 19 & $\triangleq$ & Uruguay & 176,215 & $3,444,006$ & 18.87 & Montevideo \\
\hline \multirow[t]{2}{*}{20} & 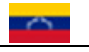 & Venezuela & 916,445 & $31,568,179$ & 31.59 & Caracas \\
\hline & & Total & $20,010,644$ & $626,441,659$ & & \\
\hline
\end{tabular}

The identity of the Latin-American Union is the proposed shield, which is shown in Figure 1. Notice that the shield is written in Latin, not in Spanish, nor Portuguese nor French. The term Unionis Latinoamericana simply means Latin-American Union. The three words considered inherent and relevant characteristics of Latin America are: 1) Libertatem (meaning freedom), because it is in freedom that all twenty Latin-American candidates may choose to join, 2) Culturum (meaning culture), because Latin-America is characterized by an incredibly rich culture due to its historical and cultural blending, and 3) Inventa (meaning discovery), because invention and discovery are characteristically "Latino", the people of Latin America are particularly inventive. 


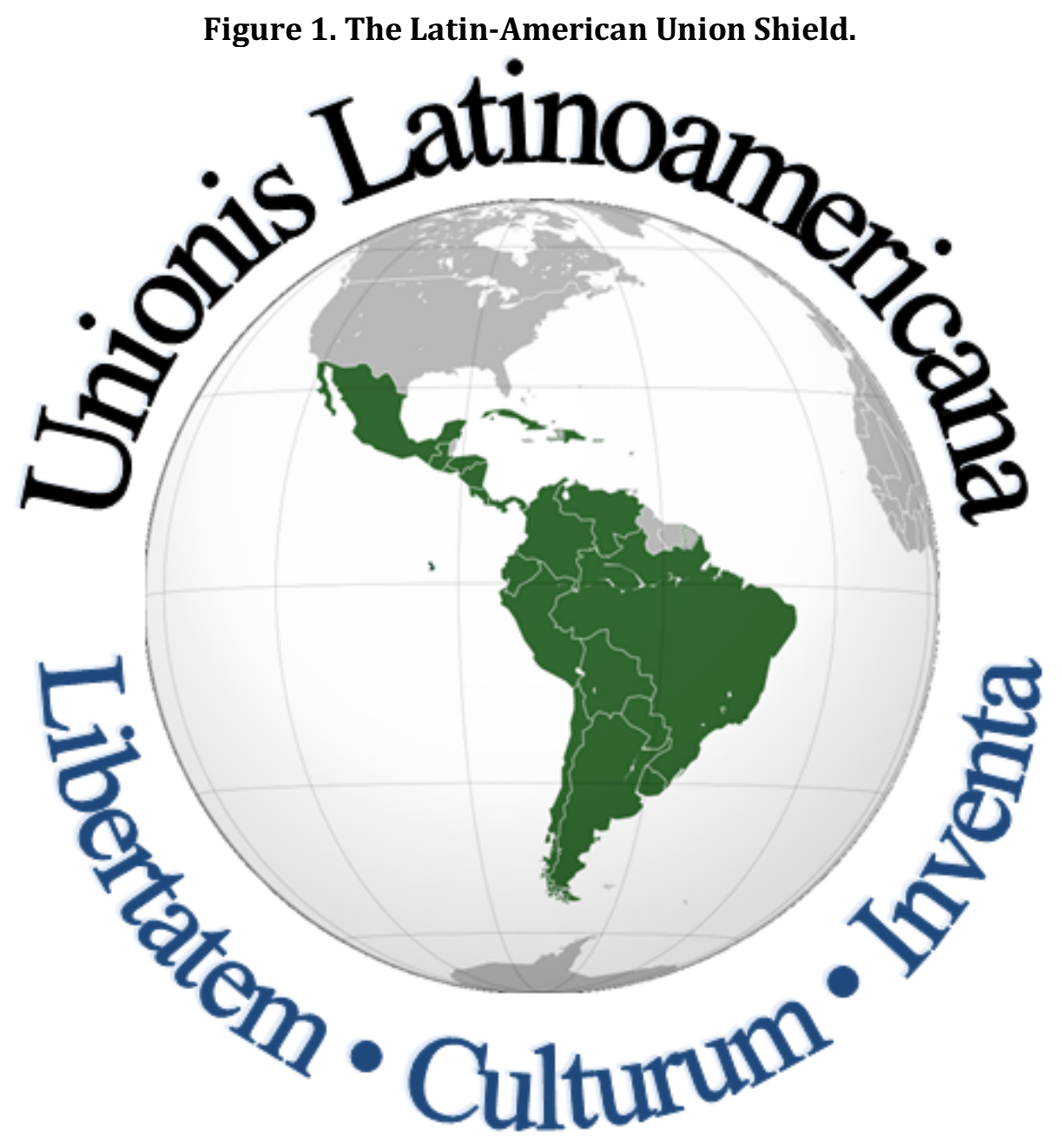

Table 2 shows the Gross Domestic Product (GDP), both nominal and at Purchasing Power Parity (PPP) for all twenty candidate Latin-American Union countries for year 2015 (Knoema, 2020). The relative sizes of the economies are also shown, highlighting the three largest economies: Argentina, Brazil and Mexico. The total percentage of the value (relative contribution) of the largest three economies is shown at the bottom of Table 2 . These three economies are the largest in Latin-America. The reasoning for LAT functioning will be done considering as members of the Latin-American Union only these three economies. This is in order to facilitate calculations and avoid confusions with the reasoning followed. Clearly, more countries could be considered in the calculations. 
Table 2. Gross Domestic Product (GDP) both nominal and at Purchasing Power Parity (PPP).

\begin{tabular}{|c|c|c|c|c|c|c|c|}
\hline \multirow{2}{*}{$\begin{array}{l}\text { No. } \\
\text { (k) }\end{array}$} & Country & \multicolumn{2}{|c|}{$\begin{array}{c}\text { GDP (Nominal) } \\
2015 \text { (Billions of } \\
\text { USD) }\end{array}$} & \multicolumn{2}{|c|}{$\begin{array}{l}\text { GDP (PPP) } \\
2015 \text { (Billions } \\
\text { of USD) }\end{array}$} & $\begin{array}{c}\text { Percentage } \\
\text { GDP } \\
\text { (Nominal) }\end{array}$ & \multirow{2}{*}{$\begin{array}{c}\text { Percentage } \\
\text { GDP (PPP) }\end{array}$} \\
\hline & Argentina & $\$$ & 601.70 & $\$$ & 972.30 & $12.21 \%$ & \\
\hline 2 & Bolivia & $\$$ & 33.50 & $\$$ & 73.90 & $0.68 \%$ & $0.79 \%$ \\
\hline 3 & Brazil & $\$$ & $1,799.60$ & $\$$ & $3,207.90$ & $36.52 \%$ & $34.16 \%$ \\
\hline 4 & Chile & $\$$ & 240.00 & $\$$ & 424.30 & $4.87 \%$ & $4.52 \%$ \\
\hline 5 & Colombia & $\$$ & 300.98 & $\$$ & 724.16 & $6.11 \%$ & $7.71 \%$ \\
\hline 6 & Costa Rica & $\$$ & 51.60 & $\$$ & 74.10 & $1.05 \%$ & $0.79 \%$ \\
\hline 7 & Cuba & & $\mathrm{N} / \mathrm{A}$ & & $\mathrm{N} / \mathrm{A}$ & $\mathrm{N} / \mathrm{A}$ & $\mathrm{N} / \mathrm{A}$ \\
\hline 8 & Dominican Republic & $\$$ & 66.60 & $\$$ & 147.60 & $1.35 \%$ & $1.57 \%$ \\
\hline 9 & Ecuador & $\$$ & 98.90 & $\$$ & 181.80 & $2.01 \%$ & $1.94 \%$ \\
\hline 10 & El Salvador & $\$$ & 25.70 & $\$$ & 52.90 & $0.52 \%$ & $0.56 \%$ \\
\hline 11 & Guatemala & $\$$ & 63.20 & $\$$ & 125.60 & $1.28 \%$ & $1.34 \%$ \\
\hline 12 & Haiti & $\$$ & 8.80 & $\$$ & 19.00 & $0.18 \%$ & $0.20 \%$ \\
\hline 13 & Honduras & $\$$ & 19.90 & $\$$ & 41.00 & $0.40 \%$ & $0.44 \%$ \\
\hline 14 & Mexico & $\$$ & $1,161.00$ & $\$$ & $2,220.10$ & $23.56 \%$ & $23.64 \%$ \\
\hline 15 & Nicaragua & $\$$ & 12.30 & $\$$ & 31.20 & $0.25 \%$ & $0.33 \%$ \\
\hline 16 & Panama & $\$$ & 47.50 & $\$$ & 82.20 & $0.96 \%$ & $0.88 \%$ \\
\hline 17 & Paraguay & $\$$ & 29.10 & $\$$ & 60.80 & $0.59 \%$ & $0.65 \%$ \\
\hline 18 & Peru & $\$$ & 179.90 & $\$$ & 385.40 & $3.65 \%$ & $4.10 \%$ \\
\hline 19 & Uruguay & $\$$ & 55.00 & $\$$ & 74.20 & $1.12 \%$ & $0.79 \%$ \\
\hline 20 & Venezuela & $\$$ & 131.90 & $\$$ & 491.60 & $2.68 \%$ & $5.24 \%$ \\
\hline & Total & $\$$ & $4,927.18$ & $\$$ & $9,390.06$ & $72.30 \%$ & $68.16 \%$ \\
\hline
\end{tabular}

Concepts such as the Big Mac index (The Economist, 2019), inflation (Fischer, Dornbusch, \& Schmalensee, 1990; Wonnacott \& Wonnacott, 1982; Friedman, 2008) and the value of money through time (Newnan, 1988; Copertari Isaacson, 2014), Purchasing Power Parity or PPP (Krugman, Obstfeld, \& Melitz, 2018), as well as complementary currencies (Hallsmith \& Lietaer, 2011; Lietaer, 2001; Greco, Jr., 2009; Lietaer \& Dunne, 2013) are considered. This paper focuses on policy development for the correct implementation of the Latin-American Union and the LAT. Data has been compiled from April 2000 to October 2019 to do the corresponding analysis (The Economist, 2019; The Big Mac Index Spreadsheet, 2019; Banco de México, 2019).

\section{VALUING THE LAT (THE BIG MAC INDEX)}

The value of the LAT given in the local currencies of the corresponding countries is calculated using the Big Mac index (The Economist, 2019). Let $\mathrm{P}_{\mathrm{k}, \mathrm{t}}$ be the price of a Big Mac for country $\mathrm{k}$ at time $t$ given in the local currency per Big Mac. Also, let $\mathrm{P}_{0, \mathrm{t}}$ be the price of a Big Mac in the United States (where $\mathrm{k}=0$ ). Then, the implicit value of the local currency of country $\mathrm{k}$ at time $\mathrm{t}$ $\left(\mathrm{I}_{\mathrm{k}, \mathrm{t}}\right)$ versus the USD is given according to equation (1).

$$
\mathrm{I}_{\mathrm{k}, \mathrm{t}}=\frac{\mathrm{P}_{\mathrm{k}, \mathrm{t}}}{\mathrm{P}_{0, \mathrm{t}}}, \mathrm{k}=1, \ldots, 20
$$

The value of $I_{k, t}$ is the actual value the USD should have given in the local currency of country $k$. However, the USD has another value, which is the official value of the USD given in the local currency per USD for country $\mathrm{k}$ at time $\mathrm{t}\left(\mathrm{O}_{\mathrm{k}, \mathrm{t}}\right)$. The Purchasing Power Parity of country k at 
time $t\left(P_{P P}, t\right)$ is given in equation (2). The PPP indicates how overvalued (for PPP > 1) or undervalued (for PPP $<1$ ) the USD is with respect to each local currency.

$$
\operatorname{PPP}_{\mathrm{k}, \mathrm{t}}=\frac{\mathrm{O}_{\mathrm{k}, \mathrm{t}}}{\mathrm{I}_{0, \mathrm{t}}}, \mathrm{k}=1, \ldots, 20
$$

We should aim for a PPP $=1$. Thus, the value of the LAT is such that makes no overvaluation or undervaluation with respect to the USD. Let $\mathrm{L}_{\mathrm{k}, \mathrm{t}}$ be the value of the LAT given in local currency per LAT for country $\mathrm{k}$ at time $\mathrm{t}$. Then, $\mathrm{L}_{\mathrm{k}, \mathrm{t}}$ is given according to equation (3). Notice that the units of $\mathrm{L}_{\mathrm{k}, \mathrm{t}}$ are the local currency per LAT, not the local currency per USD, as is the case for $\mathrm{I}_{\mathrm{k}, \mathrm{t}}$. Thus, equation (3) changes the units from local currency per USD (such as, for example, MXN/USD for the case of Mexico where $\mathrm{k}=14$ ) to local currency per LAT.

$$
\mathrm{L}_{\mathrm{k}, \mathrm{t}}=\mathrm{I}_{\mathrm{k}, \mathrm{t}}=\frac{\mathrm{P}_{\mathrm{k}, \mathrm{t}}}{\mathrm{P}_{0, \mathrm{t}}}, \mathrm{k}=1, \ldots, 20
$$

\section{THE LATIN-AMERICAN CENTRAL BANK (LACB)}

In order to manage issuing and assigning LATs, the creation of a Latin-American Central Bank (LACB) is proposed. This bank has the purpose of making sure the LAT remains functioning properly, by issuing LATs to the governments (and local banks when necessary) of receiving Latin-American Union members as required. The LAT has legal tender, that is, it can be exchanged in the local banks of Latin-American Union members by the corresponding local currency. However, the LAT is not a fiat currency, that is, it cannot be exchanged in stores for goods or services. In order to activate the LATs anyone has, it is necessary to convert them to the local currency or, if someone needs LATs, it has to buy them from their local bank of choice by exchanging the local currency for LATs. An exchange spread of $10 \%$ of the value of the LAT in the respective local currencies is initially proposed. Also, half of that LAT exchange revenue (5\%) should go to the local bank making the exchange and the other half (the other 5\%) should go to the local branch of the LAT (LACB) in each Latin-American Union participating country. The LACB should promote regional development in areas such as infrastructure and educational opportunities creation. Additionally, the LACB is responsible for making sure the right amount of LATs is circulating in Latin-American Union member countries.

\section{SIMPLE EXAMPLE OF LAT FUNCTIONING}

In order to understand how the LAT is meant to function within the Latin-American Union, a realistically enough example (for $t=$ October 2019) will be used. Suppose Mexico, Brazil and Argentina are members of the Latin-American Union. Also, suppose the Big Mac costs in Mexico \$50 MXN/Big Mac, in Brazil it costs \$15 BRL/Big Mac and in Argentina it costs \$75 ARS/Big Mac. Also, the price of a Big Mac in the United States is \$5 USD/Big Mac. Then, the prices of the LAT in Mexico, Brazil and Argentina are $\mathrm{L}_{14}=(50 \mathrm{MXN} / \mathrm{Big} \mathrm{Mac}) /(\$ 5 \mathrm{USD} / \mathrm{Big} \mathrm{Mac})=\$ 10$ $\mathrm{MXN} / \mathrm{LAT}, \mathrm{L}_{3}=(\$ 15 \mathrm{BRL} / \mathrm{Big} \mathrm{Mac}) /(\$ 5 \mathrm{USD} / \mathrm{Big} \mathrm{Mac})=\$ 3 \mathrm{BRL} / \mathrm{LAT}$ and $\mathrm{L}_{1}=(\$ 75 \mathrm{ARS} / \mathrm{Big}$ $\mathrm{Mac}) /(\$ 5 \mathrm{USD} / \mathrm{Big} \mathrm{Mac})=\$ 15 \mathrm{ARS} / \mathrm{LAT}$, respectively. Assume there are three branches of the Latin-American Central Bank (LACB) in Mexico, Brazil and Argentina located in Mexico City, Brasília and Buenos Aires, called LACB Mexico, LACB Brazil and LACB Argentina, respectively. Also, the local banks of choice are BBVA Mexico, BBVA Brazil and BBVA Argentina. The exchange spread is $10 \%$ (half of that goes to the local banks and the other half to the LACB local branches), which means that the purchasing/selling prices of the LAT in Mexico are $\$ 10 \times 0.95=\$ 9.5 \mathrm{MXN} / \mathrm{LAT}$ and $\$ 10 \times 1.05=\$ 10.5 \mathrm{MXN} / \mathrm{LAT}$, respectively, for Brazil the purchasing/selling prices of the LAT are $\$ 3 \times 0.95=\$ 2.85 \mathrm{BRL} / \mathrm{LAT}$ and $\$ 3 \times 1.05=\$ 3.15$ BRL/LAT, respectively, and for Argentina the purchasing/selling prices of the LAT are $\$ 15 \times 0.95=\$ 14.25$ ARS/LAT and $\$ 15 \times 1.05=\$ 15.75$ ARS/LAT, respectively. 
This story begins in Mexico. Suppose the SCT (Communications and Transportation Secretary) of the Mexican government requests the Mexican branch of the Latin-American Central Bank (LACB Mexico) in Mexico City \$100’000,000 LATs to construct 5G telecommunication infrastructure reaching isolated rural areas in Mexico. The LACB issues free credit to the Mexican government and the SCT in particular for LAT $\$ 100^{\prime} 000,000$ to be received at BBVA Mexico. SCT requires half of that money to buy goods and services from the USA for 5G construction and the other half of the money to pay for labor and other costs in Mexico. Thus, SCT sells its LATs to BBVA Mexico for \$100’000,000 LAT $\times \$ 9.5 \mathrm{MXN} / \mathrm{LAT}=\$ 950 \prime 000,000 \mathrm{MXN}$. Half of that money is exchanged for USD and the other half is used for the construction of the $5 \mathrm{G}$ infrastructure required.

Now, BBVA has $\$ 100$ '000,000 LATs worth of credit. What can it do with that? Suppose, AeroMexico requires buying jet planes for its fleet. Instead of buying them from Boeing, they decide to buy them from Embraer (a Brazilian company). AeroMexico requires LATs for that purpose. Assume that, coincidentally, they also need $\$ 100$ '000,000 LATs, so they buy those LATs from BBVA Mexico for $\$ 100 \prime 000,000$ LAT $\times \$ 10.5 \mathrm{MXN} / \mathrm{LAT}=\$ 1,050 \prime 000,000 \mathrm{MXN}$. BBVA Mexico just gained $\$ 1,050^{\prime} 000,000 \mathrm{MXN}-\$ 950^{\prime} 000,000 \mathrm{MXN}=\$ 100^{\prime} 000,000 \mathrm{MXN}$. BBVA Mexico keeps half of that for their banking services and gives the Mexican Branch of the LatinAmerican Central Bank (LACB Mexico) the other half. Thus, BBVA Mexico has just earned $\$ 50$ '000,000 MXN and LACB Mexico has credit in BBVA Mexico for \$50'000,000 MXN, which they can use to pay for their money management and money issuing costs. With that money ( $\$ 100 ' 000,000$ LATs) AeroMexico exchange them for BRL in BBVA Brazil, by buying $\$ 100^{\prime} 000,000 \mathrm{LAT} \times \$ 2.85 \mathrm{BRL} / \mathrm{LAT}=\$ 285^{\prime} 000,000 \mathrm{BRL}$. They use that money to purchase the corresponding number of jet planes from Embraer.

What does BBVA Brazil do with $\$ 100^{\prime} 000,000$ LATs worth of credit? Suppose, there is a Brazilian entrepreneur who wants to buy beef from an Argentinian beef supplier called "Frigorífico Gorina". They need LATs to be able to buy beef from the Argentinian beef seller. Suppose that, coincidentally, they also want $\$ 100 \prime 000,000$ LATs worth of beef. So they purchase $\$ 100 \prime 000,000$ LATs from BBVA Brazil by paying $\$ 100$ '000,000 LAT $\times \$ 3.15 \mathrm{BRL} / \mathrm{LAT}=$ $\$ 315^{\prime} 000,000$ BRL. In this exchange, BBVA Brazil makes \$315’000,000 BRL - \$285'000,000 $\mathrm{BRL}=\$ 30^{\prime} 000,000 \mathrm{BRL}$. BBVA Brazil keeps half of that money for their money management costs and they credit the Latin-American Central Bank branch in Brazil (LACB Brazil) BRL $\$ 15^{\prime} 000,000$ to pay for their LAT management costs.

With the $\$ 100$ '000,000 LATs, the Brazilian entrepreneur exchange them for Argentinian pesos. He receives $\$ 100 \prime 000,000$ LATs $\times \$ 14.25$ ARS/LAT $=\$ 1,425^{\prime} 000,000$ ARS and he buys the corresponding amount of beef from "Frigorífico Gorina". Now, suppose there is an Argentinian entrepreneur who wants to buy Tequila from the "Don Julio" brand. He needs LATs for that purpose. If this entrepreneur also wants to buy $\$ 100$ '000,000 LATs worth of Mexican Tequila, he needs to exchange his Argentinian pesos for LATs. He gives $\$ 100$ '000,000 LATs $\times \$ 15.75$ ARS $/$ LAT $=\$ 1,575^{\prime} 000,000$ ARS. He gives that money to BBVA Argentina. Now, BBVA Argentina has made $\$ 1,575^{\prime} 000,000$ ARS $-\$ 1,425^{\prime} 000,000$ ARS $=\$ 150 \prime 000,000$ ARS. BBVA Argentina gains half of that money and delivers the other half of that money to the Argentinian branch of the Latin-American Central Bank (LACB Argentina). BBVA Mexico exchanges those LATs for MXN in order to deliver the Argentinian entrepreneur the corresponding amount of "Don Julio" Tequila. And the story goes on and on.

What is important to realize is that issuing the initial credit of LAT $\$ 100$ '000,000 in Mexico "for free" promotes commerce and the production of goods and services within Latin-America. All the branches of BBVA make money out of it and the Latin-American Central Bank branches also 
receive money to pay for their LAT management activities in the respective local currencies for each branch the LACB is located in. This example illustrates how money has value as long as people believe in that value. Clearly, few things are as abstract and fragile as money.

\section{THE PROBLEM WITH LAT'S PROPER FUNCTIONING}

As the previous example illustrates, in order for the LAT to have value, it is necessary that people buy and sell LATs in their corresponding countries to buy goods from other countries. Both operations (buying and selling of LATs) are required in order for local banks not to get stocked with LATs they do not use or not having enough LATs as required. But people would only use the LAT to buy/sell or invest in other Latin-American Union members if doing so is cheaper than using the USD.

A thorough analysis of an example is required. This analysis will be carried out using approximated values in order not to cloud the calculations with unnecessary decimal values. Also, the analysis assumes $t=$ October 2019. Suppose the official prices of the USD for Argentina, Brazil and Mexico are $\mathrm{O}_{1}=\$ 60 \mathrm{ARS} / \mathrm{USD}, \mathrm{O}_{3}=\$ 4 \mathrm{BRL} / \mathrm{USD}$, and $\mathrm{O}_{14}=\$ 20$ MXN/USD, respectively. The values of the LAT are the ones calculated in the previous section, that is $\mathrm{L}_{1}=\$ 75 / \$ 5=\$ 15 \mathrm{ARS} / \mathrm{LAT}, \mathrm{L}_{3}=\$ 15 / \$ 5=\$ 3 \mathrm{BRL} / \mathrm{LAT}$ and $\mathrm{L}_{14}=\$ 50 / \$ 5=\$ 10$ MXN/LAT for Argentina $(\mathrm{k}=1)$, Brazil $(\mathrm{k}=3)$ and Mexico $(\mathrm{k}=14)$, respectively.

The Purchasing Power Parity (PPP) calculations are $\mathrm{PPP}_{1}=\$ 60 / \$ 15=4.0, \mathrm{PPP}_{3}=\$ 4 / \$ 3=1.33$, and $\mathrm{PPP}_{14}=\$ 20 / \$ 10=2.00$, for Argentina, Brazil and Mexico, respectively.

\section{The case for Argentina $\leftarrow$ Brazil (transaction type number (1))}

The first case to consider is to import one-dollar worth of goods or services from Brazil into Argentina. How many BRL do I need to buy one-dollar worth of merchandise from Brazil? Since $\mathrm{O}_{3}=\$ 4 \mathrm{BRL} / \mathrm{USD}$, I need $\$ 4 \mathrm{BRL} / \mathrm{USD}$ to purchase one dollar of merchandise in Brazil. If I used LATs instead, I could buy LATs in Argentina and exchange those LATs for BRL in Brazil. I need $\$ 4 \mathrm{BRL} / \mathrm{USD}$. Thus, I need $\mathrm{O}_{3} / \mathrm{L}_{3}=(\$ 4 \mathrm{BRL} / \mathrm{USD}) /(3 \mathrm{BRL} / \mathrm{LAT})=1.33 \mathrm{LAT} / \mathrm{USD}$. In order to get $1.33 \mathrm{LAT} /$ USD in Argentina, I need $\left(\mathrm{O}_{3} / \mathrm{L}_{3}\right) \times \mathrm{L}_{1}=(1.33 \mathrm{LAT} / \mathrm{USD}) \times(\$ 15$ ARS/LAT $)=(\$ 20$ ARS/USD). However, one-dollar in Argentina is worth $0_{1}=(\$ 60$ ARS/USD). Thus, it is cheaper to use LATs instead of USD to buy (import) merchandise from Brazil to Argentina.

\section{The case for Argentina $\rightarrow$ Brazil (transaction type number 2)}

What about the other way around? If I want to buy one-dollar worth of merchandise in Argentina to import it to Brazil, I need $\mathrm{O}_{1}=\$ 60 \mathrm{ARS} / \mathrm{USD}$. This is equivalent to $\mathrm{O}_{3}=\$ 4$ BRL/USD. Thus, it costs $\$ 4 \mathrm{BRL} / \mathrm{USD}$ in Brazil to buy one-dollar worth of merchandise to import it from Argentina to Brazil using USD. What about using LATs? To get \$60 ARS I need $\left(\mathrm{O}_{1} / \mathrm{L}_{1}\right)=(\$ 60 \mathrm{ARS} / \mathrm{USD}) /(\$ 15 \mathrm{ARS} / \mathrm{LAT})=\$ 4 \mathrm{LAT} / \mathrm{USD}$. In Brazil, that is $\left(\mathrm{O}_{1} / \mathrm{L}_{1}\right) \times \mathrm{L}_{3}=(4$ LAT/USD) $\times \$ 3 \mathrm{BRL} / \mathrm{LAT}=\$ 12 \mathrm{BRL} / \mathrm{USD}$. Clearly, paying $\$ 12 \mathrm{BRL} / \mathrm{USD}$ is more expensive than simply using the USD and paying $\$ 4 \mathrm{BRL} / \mathrm{USD}$. Consequently, it makes no economic sense to use the LAT to import from Argentina. But commerce both ways is required. What can we do? The LACB needs to intervene.

\section{The case for Argentina $\leftarrow$ Mexico (transaction type number (3))}

Suppose I want to buy one-dollar worth of goods from Mexico to import to Argentina. That is $\mathrm{O}_{14}=\$ 20 \mathrm{MXN} / \mathrm{USD}$, which is equivalent to $\mathrm{O}_{1}=\$ 60 \mathrm{ARS} / \mathrm{USD}$. How many LATs do I need to sell in Mexico to get $\$ 20 \mathrm{MXN}$ ? That is $\mathrm{O}_{14} / \mathrm{L}_{14}=(\$ 20 \mathrm{MXN} / \mathrm{USD}) /(\$ 10 \mathrm{MXN} / \mathrm{LAT})=\$ 2$ LAT/USD. In order to get $\$ 2 \mathrm{LAT} / \mathrm{USD}$ in Mexico, I need $\left(\mathrm{O}_{14} / \mathrm{L}_{14}\right) \times \mathrm{L}_{1}=(2 \mathrm{LAT} / \mathrm{USD}) \times \$ 15$ ARS/LAT $=\$ 30$ ARS/USD in Argentina. Since in Argentina the dollar is worth $0_{1}=\$ 60$ 
ARS/USD, that is half of the \$30 ARS/USD I need if I use LATs. Consequently, it makes sense to use the LAT instead of the USD to buy merchandise from Mexico to import it to Argentina.

\section{The case for Argentina $\rightarrow$ Mexico (transaction type number 4)}

Now, what I want to do is to buy one-dollar worth of merchandise from Argentina to import it to Mexico. That is $\mathrm{O}_{1}=\$ 60 \mathrm{ARS} / \mathrm{USD}$. In Mexico, one USD costs $\mathrm{O}_{14}=\$ 20 \mathrm{MXN} / \mathrm{USD}$. How many MXN/USD would I need if I use the LAT instead? That would be $\left(0_{1} / \mathrm{L}_{1}\right)=(\$ 60 \mathrm{ARS} / \mathrm{USD}) /(\$ 15$ ARS $/ \mathrm{LAT})=\$ 4 \mathrm{LAT} / \mathrm{USD}$. In order to get $\$ 4 \mathrm{LAT} / \mathrm{USD}$ in Argentina, I need $\left(\mathrm{O}_{1} / \mathrm{L}_{1}\right) \times \mathrm{L}_{14}=(4$ $\mathrm{LAT} / \mathrm{USD}) \times 10 \mathrm{MXN} / \mathrm{LAT}=\$ 40 \mathrm{MXN} / \mathrm{USD}$, which is twice as expensive as the USD, being the latter $\mathrm{O}_{14}=\$ 20 \mathrm{MXN} / \mathrm{USD}$. Thus, it is better to use USD instead of LAT for the exchange. Once again, what can we do? The LACB needs to inject LATs into Mexico (at the right value) so that they can be exchanged for ARS in Argentina.

\section{The case for Brazil $\rightarrow$ Mexico (transaction type number (5))}

If I want to buy one-dollar worth of goods from Brazil and import it to Mexico, I need to have in Brazil \$4 BRL/USD. In Mexico one USD would be \$20 MXN/USD. What if I use the LAT instead? I need $\left(\mathrm{O}_{3} / \mathrm{L}_{3}\right)=(\$ 4 \mathrm{BRL} / \mathrm{USD}) /(\$ 3 \mathrm{BRL} / \mathrm{LAT})=1.33 \mathrm{LAT} / \mathrm{USD}$. How many LATs do I need to buy in Mexico? That would be $\left(\mathrm{O}_{3} / \mathrm{L}_{3}\right) \times \mathrm{L}_{14}=(1.33 \mathrm{LAT} / \mathrm{USD}) \times \$ 10 \mathrm{MXN} / \mathrm{LAT}=\$ 13.33$ MXN/USD. In Mexico, the dollar is worth $\$ 20$ MXN/USD. Thus, it is cheaper to use the LAT to import goods from Brazil to Mexico.

\section{The case for Brazil $\leftarrow$ Mexico (transaction type number 6 )}

Finally, what if we want to import goods from Mexico to Brazil? One-dollar worth of goods in Mexico is $\mathrm{O}_{14}=\$ 10 \mathrm{MXN} / \mathrm{USD}$. In Brazil, the dollar is worth $\$ 4 \mathrm{BRL} / \mathrm{USD}$. If we used LATs, how many BRL/USD would we need? I need in Brazil $\left(\mathrm{O}_{14} / \mathrm{L}_{14}\right) \times \mathrm{L}_{3}=((\$ 20 \mathrm{MXN} / \mathrm{USD}) /(\$ 10$ MXN/LAT $) \times(\$ 3 \mathrm{BRL} / \mathrm{LAT})=\$ 6 \mathrm{BRL} / \mathrm{USD}$. We have that $\$ 6 \mathrm{BRL} / \mathrm{USD}$ is more expensive than $\$ 4 \mathrm{BRL} / \mathrm{USD}$, so that using the LAT to buy (import) merchandise from Mexico into Brazil makes no sense. Thus, the LACB would have to inject LAT into Brazil to buy from Mexico.

\section{RESULTS FROM THE ANALYSIS AND THEORETICAL DERIVATION THROUGH INDUCTION}

The result is that for Brazil to import goods either from Argentina or from Mexico, it needs the LACB to inject LATs into Brazil for such purposes. Also, for importing from Argentina to Mexico, the LACB needs to inject LATs in Mexico for such purpose. However, it is not necessary to inject LATs for importing from Brazil to Argentina, from Brazil to Mexico and from Mexico to Argentina. Notice that it is better to use LATs instead of the USD when the PPP for the exporting country is less than the PPP for the importing country. Why is that?

By induction, it is possible to generalize the analysis from section 5. Suppose there are two countries: Country X and Country Y. Country X wants to import from country $\mathrm{Y}$ (which is the same as saying that Country $\mathrm{Y}$ is exporting to Country X). Thus, we have the relationship Country $\mathrm{X} \leftarrow$ Country $\mathrm{Y}$. Then, it is better to use the LAT if, and only if, the inequality in equation (4) is satisfied.

$$
\frac{\mathrm{O}_{\mathrm{Y}}}{\mathrm{L}_{\mathrm{Y}}} \times \mathrm{L}_{\mathrm{X}}<\mathrm{O}_{\mathrm{X}}
$$

Accommodating terms in equation (4) results in equation (5).

$$
\frac{O_{Y}}{L_{Y}} \times \frac{L_{X}}{O_{X}}<1
$$

Notice that $P P_{Y}$ is given according to equation (6) and $P P P_{X}$ is given according to equation (7). 


$$
\begin{aligned}
& \mathrm{PPP}_{\mathrm{Y}}=\frac{\mathrm{O}_{\mathrm{Y}}}{\mathrm{L}_{\mathrm{Y}}} \\
& \mathrm{PPP}_{\mathrm{X}}=\frac{\mathrm{O}_{\mathrm{X}}}{\mathrm{L}_{\mathrm{X}}}
\end{aligned}
$$

Consequently, equation (5) can be rewritten as shown in equation (8). Equation (8) can be transformed into equation (9).

$$
\begin{aligned}
& \frac{\mathrm{PPP}_{\mathrm{Y}}}{\mathrm{PPP}_{\mathrm{X}}}<1 \\
& \mathrm{PPP}_{\mathrm{Y}}<\mathrm{PPP}_{\mathrm{X}}
\end{aligned}
$$

Equation (9) means that if the PPP of the exporting country $Y$ is less than the PPP of the importing country $\mathrm{X}$, then using LATs is more economically efficient. Otherwise, using the USD would be better, and, as a consequence, the LACB would have to inject LATs in country X so that it can import from country Y.

So, what happens if $\mathrm{PPPY}_{\mathrm{Y}}>\mathrm{PPPx}$. What is the price of the LAT for country $\mathrm{X}$ (remember that country $\mathrm{X}$ is trying to import from country Y: Country $\mathrm{X} \leftarrow$ Country $Y$ )? Taking equation (4), we solve for $\mathrm{Lx}$, resulting in equation (10).

$$
\mathrm{L}_{\mathrm{X}}<\mathrm{O}_{\mathrm{X}} \times \frac{\mathrm{L}_{\mathrm{Y}}}{\mathrm{O}_{\mathrm{Y}}}, \text { if } \mathrm{PPP}_{\mathrm{Y}}>\mathrm{PPP}_{\mathrm{X}}
$$

\section{INTERNATIONAL ARBITRAGE AND THE LAT}

Can the LAT be used by speculators to make a profit? Well..., yes it can. In Finance, this is called arbitrage (Brealey \& Myers, 1991). So, let us consider the most extreme case: Argentina and Brazil. Argentina has a $\mathrm{PPP}_{1}=(\$ 60$ ARS/USD $) /(\$ 15$ ARS $/$ USD $)=4$ and Brazil has a $\mathrm{PPP}_{3}=(\$ 4$ $\mathrm{BRL} / \mathrm{USD}) /(\$ 3 \mathrm{BRL} / \mathrm{USD})=1.33$.

$\mathrm{A} \mathrm{PPP}_{1}=4$ for Argentina means that the USD is worth four times what it should be worth in Argentina, whereas a $\mathrm{PPP}_{3}=1.33$ for Brazil means that such USD is only worth 1.33 times as much as it should according to the Big Mac index.

What could a speculator do? Since the USD is worth more in Argentina than in Brazil, he can transfer \$1 USD from his bank in the USA to a bank in Argentina, say, for example, BBVA Argentina. At BBVA Argentina he can convert that USD for ARS (Argentinian pesos). Since $\mathrm{O}_{1}=$ $\$ 60 \mathrm{ARS} / \mathrm{USD}$, the speculator would receive $\$ 1 \mathrm{USD} \times \$ 60 \mathrm{ARS} / \mathrm{USD}=\$ 60 \mathrm{ARS}$. Then, he can buy LATs for that amount, receiving $(\$ 60 \mathrm{ARS}) /(\$ 15 \mathrm{ARS} / \mathrm{LAT})=\$ 4$ LATs. After that, he can transfer those \$4 LATs to a local bank in Brazil, say, BBVA Brazil. At BBVA Brazil, he can convert those $\$ 4$ LATs to BRL, receiving $\$ 4$ LATs $\times \$ 3$ BRL/LAT $=\$ 12$ BRL. Finally, he can convert those $\$ 12 \mathrm{BRL}$ for USD, receiving (\$12 BRL)/(\$4 BRL/USD) = \$3 USD and transfer those $\$ 3$ USD back to his bank in the USA. He invested USD \$1 and received USD \$3, which is a $200 \%$ profit.

Equation (11) gives the profit a speculator could make between country X and country $Y,($ ), where $\mathrm{PPP}_{\mathrm{X}}>\mathrm{PPP}_{\mathrm{Y}}$ when having a relationship between country $\mathrm{X}$ and country $\mathrm{Y}$ as Country $\mathrm{X}$ $\leftarrow$ Country Y.

$$
\rho=\left({ }^{P P P_{X}} / \mathrm{PPP}_{\mathrm{Y}}-1\right) \times 100 \% \text {, where } \mathrm{PPP}_{\mathrm{X}}>\mathrm{PPP}_{\mathrm{Y}}
$$


Although this may look bad, in Finance, arbitrage (that is, the interested action of speculators trying to take advantage of the system), is a good thing, because it makes things trending to a situation where such speculation is no longer possible. In this case, the speculator sold USD in Argentina for ARS (which seems to be scarce for having such a large official value of $\$ 60$ ARS/USD), thus creating financial pressure for the USD not to be as over-valuated in Argentina as it is, which would tend to decrease the official price of the USD in Argentina. On the other hand, in Brazil, the speculator bought USD for BRL (which seems not to be as scarce for having a lower over-valuation than the one the USD has in Argentina), thus creating financial pressure to increase the value of the USD in Brazil. The combination of these two trends tends to equate the PPPs of both countries, and as a consequence, eliminate the possibility for arbitrage. In general, the activity carried out by speculators makes things trending to a more balanced situation in which, although not necessarily all PPPs would be equal to one, the PPPs of the countries participating in the Latin-American Union would tend to the same value.

Let $\mathrm{X}$ and $\mathrm{Y}$ be any two countries members of the Latin-American Union, where we have that $\mathrm{X}$ $=1,2, \ldots, 20, Y=1,2, \ldots, 20$, and $X \neq Y$. Generally speaking, we could say that equation (12) applies.

$$
\mathrm{PPP}_{\mathrm{X}} / \mathrm{PPP}_{\mathrm{Y}}=\frac{\mathrm{o}_{\mathrm{X}}}{\mathrm{L}_{\mathrm{X}}} \frac{\mathrm{L}_{\mathrm{Y}}}{\mathrm{O}_{\mathrm{Y}}}\left\{\begin{array}{lc}
>1, \mathrm{PPP}_{\mathrm{X}}>\mathrm{PPP}_{\mathrm{Y}}, & \text { Speculation from } \mathrm{X} \text { to } \mathrm{Y} \\
=1, \mathrm{PPP}_{\mathrm{X}}=\mathrm{PPP}_{\mathrm{Y}}, & \text { No speculation } \\
<1, \mathrm{PPP}_{\mathrm{Y}}>\mathrm{PPP}_{\mathrm{X}}, & \text { Speculation from } \mathrm{Y} \text { to } \mathrm{X}
\end{array}\right.
$$

The reason there is no speculation if both values for the PPP are equal is because one dollar is worth the same in both countries, so there is no chance for speculation. However, if we have that $\mathrm{PPP}_{\mathrm{X}}>\mathrm{PPP}_{\mathrm{Y}}$, it means the dollar is worth more in country $\mathrm{X}$ than in country $\mathrm{Y}$ (in the previous example, $X=1$ and $Y=3$, that is, Argentina and Brazil, respectively), so that by transferring USD to $X$, buying the local currency of $X$ and with that buying LAT in $X$ and then transferring those LAT to Y, buying the local currency of Y with those LAT and finally buying USD with the local currency of Y gives the profit margin indicated in equation (11). The inverse is also possible. If $\mathrm{PPP}_{\mathrm{Y}}>\mathrm{PPP}_{\mathrm{X}}$, it means the USD is worth more in country $\mathrm{Y}$ than in country $\mathrm{X}$, so that the inverse speculative type of transaction (going from $\mathrm{Y}$ to $\mathrm{X}$ ) would occur. 
Figure 2. Purchasing Power Parity (PPP) calculations for Argentina, Brazil and Mexico from April 2000 to October 2019.

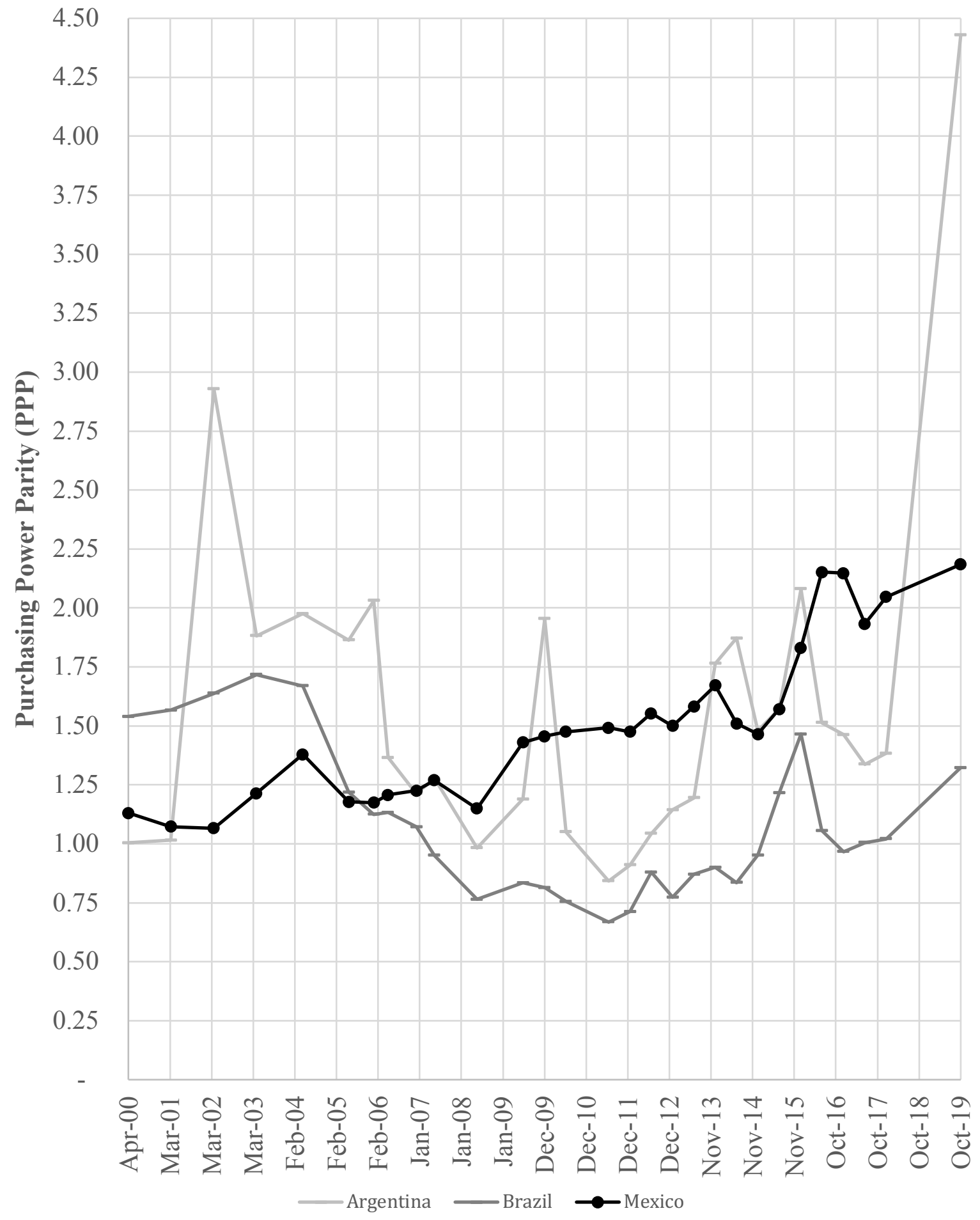

THE IMPORTANCE OF EXPORTS TO THE USA IN LATIN AMERICA

The reason why Latin-American countries tend to have an over-valuated USD (see Figure 2) is because of the incredible importance exports to the United States have in their local economies. The amount of trade among Latin-American countries is very low, whereas their economies tend to be focused on exporting to the United States. Having an over-valuated USD gives Latin-American exporters a competitive advantage, because they receive USDs in exchange for their goods and services exported to the USD, whereas their internal costs tend to be valued in the local currency. 
Economies oriented towards exportation means Latin-American countries are not taking care of their own population by making imports (from the USA, but, in general, from all over the world) more expensive than they should. The LAT and the action of speculators through arbitrage tends to make things better for the local economies within members of the LatinAmerican Union, bringing a balanced mix between exports and imports to/from the USA and the rest of the world. Notice that in Figure 2, most countries tend to over-valuate the USD.

\section{CANCELING SPECULATION AND TRENDING TOWARDS THE SAME PPP WITHIN THE LATIN-AMERICAN UNION MEMBERS}

Speculation, particularly the brutal kind that the LAT would allow in some cases (remember the case seen in section 7 having Argentina and Brazil as participants) would not allow the LAT to be a viable alternative. We need a way to ensure such speculation does not take place or, if it does take place, it does so according to the LAT's monetary policy of choice.

\section{Ensuring there is no speculation with the LAT and the USD}

In order to avoid speculation, we need to first identify the country with the lowest PPP. If that PPP is greater than one or it is the only country with a PPP less than one, speculation and LAT monetary policy is useful. If not, we need to devaluate the local currencies of the countries with the lowest PPP so that the official value of the USD increases and thus the value for the corresponding PPP also increases. Equation (13) indicates finding country Z with the lowest PPP.

$$
\mathrm{Z}=\mathrm{h} / \min _{\mathrm{h}=1,2, \ldots, 20} \mathrm{PPP}_{\mathrm{h}}
$$

Also, let X be any country part of the Latin-American Union different than country Z. If we want to avoid speculation to occur between country X and country Z, we need that the PPP of both countries equals 1 , as indicated in equation (14).

$$
\frac{\mathrm{PPP}_{\mathrm{X}}}{\mathrm{PPP}_{\mathrm{Z}}}=1
$$

The ideal value for the LAT for country $X$ is $L_{x}$, where $L_{X}=P_{X} / P_{0}$. Also, the ideal value for the LAT of country $\mathrm{Z}$ is $\mathrm{Lz}_{z}=\mathrm{P}_{\mathrm{Z}} / \mathrm{P}_{0}$. Let $\mathrm{H}_{\mathrm{X}}$ be the price for the LAT of country $\mathrm{X}$ such that it would not generate speculation. Then, $\mathrm{PPP}_{\mathrm{X}}$ is given according to equation (15). Also, $\mathrm{PPP}_{\mathrm{Z}}$ is given according to equation (16)

$$
\begin{aligned}
& \mathrm{PPP}_{\mathrm{X}}=\frac{\mathrm{O}_{\mathrm{X}}}{\mathrm{H}_{\mathrm{X}}} \\
& \mathrm{PPP}_{\mathrm{Z}}=\frac{\mathrm{O}_{\mathrm{Z}}}{\mathrm{L}_{\mathrm{Z}}}
\end{aligned}
$$

Substituting $\mathrm{PPP}_{\mathrm{X}}$ from equation (15) and $\mathrm{PPP}_{\mathrm{Z}}$ from equation (16) into equation (14) yields equation (17).

$$
\frac{\mathrm{PPP}_{\mathrm{X}}}{\mathrm{PPP}_{\mathrm{Z}}}=\frac{\mathrm{O}_{\mathrm{X}}}{\mathrm{H}_{\mathrm{X}}} \frac{\mathrm{L}_{\mathrm{Z}}}{\mathrm{O}_{\mathrm{Z}}}=1
$$

Thus, we should set the actual price of the LAT to $\mathrm{H}_{\mathrm{X}}$ for each and every country member of the Latin-American Union $X=1,2, \ldots, 20$, where $X \neq Z$ and $Z$ has been chosen according to equation (13). Equation (18) gives the no speculation (equilibrium) value for the LAT of country X.

$$
\mathrm{H}_{\mathrm{X}}=\mathrm{O}_{\mathrm{X}} \frac{\mathrm{L}_{\mathrm{Z}}}{\mathrm{O}_{\mathrm{Z}}}
$$




\section{How to estimate the expected PPP?}

According to equation (17) the PPPs of all countries other than country Z (which has the lowest PPP of them all) will trend to the same value if we apply equation (18) to the value of the LAT for all these other countries. It is expected that the PPP will trend to a value such that the relative sizes of the corresponding economies (their Gross Domestic Product or GDP) acts as a form of pondered average.

Thus, let $w_{k}$ be the weight of the economy for country $k$ and GDP $\mathrm{G}_{\mathrm{k}}$ the GDP for country $\mathrm{k}$, where all the values for $\mathrm{k}$ (and $\mathrm{h}$ ) correspond to countries within the Latin-American Union. Then, equation (19) applies. Clearly, since it is a weighted average, the sum of all weights should equal 1 as indicated in equation (20).

$$
\begin{array}{r}
\mathrm{w}_{\mathrm{k}}=\frac{\mathrm{GDP}_{\mathrm{k}}}{\sum_{\mathrm{h}=1}^{20} \mathrm{GDP}_{\mathrm{h}}}, \mathrm{k}=1,2, \ldots, 20 \\
\sum_{\mathrm{k}=1}^{20} \mathrm{~W}_{\mathrm{k}}=1
\end{array}
$$

The weighted average of the PPP, which is to be the expected PPP towards which all PPPs trend to is given according to equation (21).

$$
\mathrm{PPP}=\sum_{\mathrm{k}=1}^{20} \mathrm{w}_{\mathrm{k}} \mathrm{PPP}_{\mathrm{k}}
$$

To exemplify, consider the data we have for Argentina, Brazil and Mexico as the only members of the Latin-American Union. It is assumed that the GDP for year 2015 can be used for all the data between April 2000 and October 2019. Figure 3 shows the results of such calculations.

Figure 3. Values towards which the PPP should trend as time goes by assuming pondered weights are based on GDP data (nominal) from 2015.

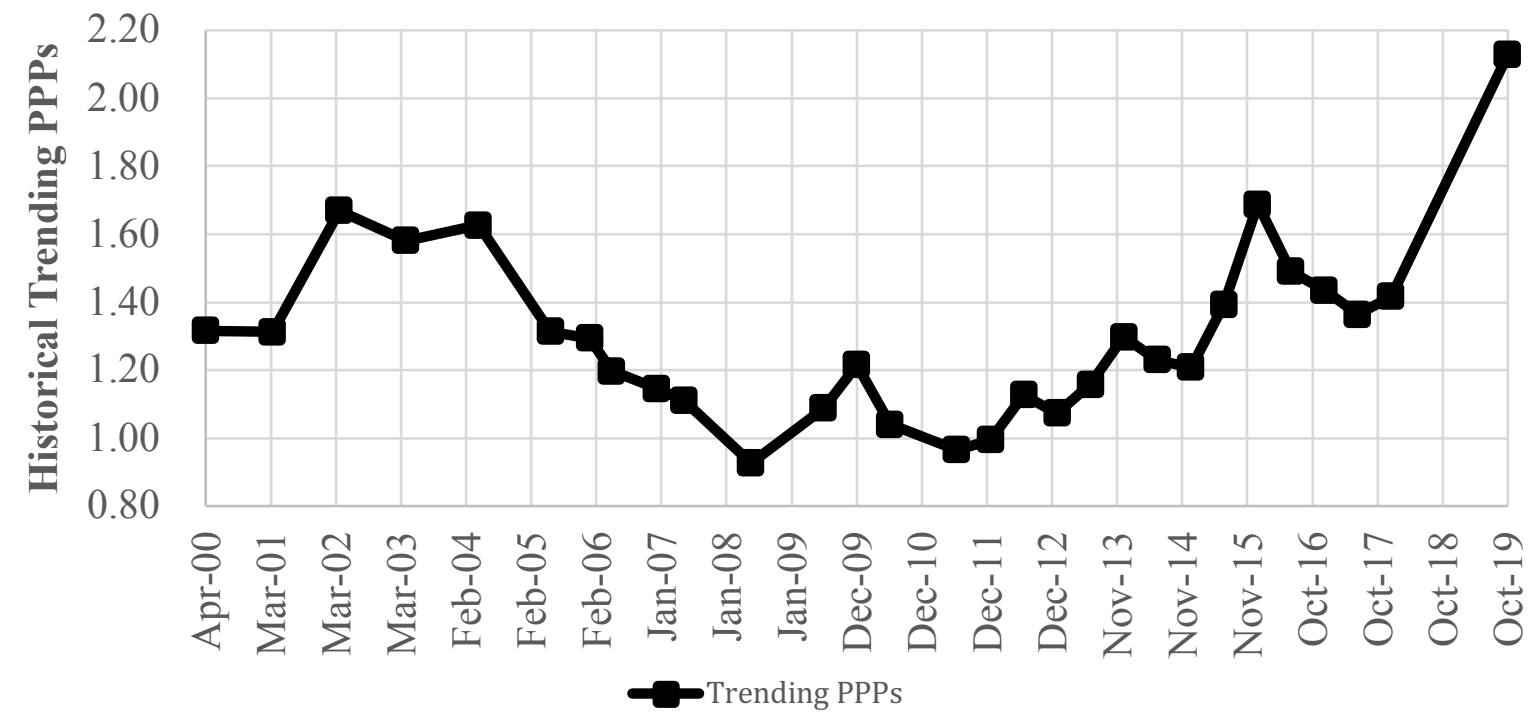

The minimum value of all historical trending values shown in Figure 3 is 0.93 and it occurs on June 2008. The maximum such value is 2.13 and it occurs on October 2019. Clearly, the unstable situation in Argentina creates pressure for the trending PPP to increase. We can also see that for the most part, the historical trending value for the PPP tends to be between 0.90 and 1.40, with a bias towards the latter. In very rare occasions the trending PPP is very near one. 


\section{DISCUSSION}

Equation (12) is the basic LAT equation indicating flow of capitals within Latin-American Union member countries. In that equation, let $\mathrm{X}$ and $\mathrm{Y}$ be any two Latin-American Union members, then, if we consider a given time for some month and year (it is assumed the situation would not change significantly in periods of time less than a month), represented in Figure 4 as mm/yyyy, and PPPx and PPPY the PPP values for countries X and Y, respectively, it is possible to have a motion represented with a black arrow for $P P P_{X}$ and $P P P_{Y}$ when $\mathrm{PPP}_{\mathrm{X}} / \mathrm{PPP}_{\mathrm{Y}}>1\left(\mathrm{PPP}_{\mathrm{X}}>\mathrm{PPP}_{\mathrm{Y}}\right)$ due to a speculative movement of capitals (USD) from the United States to X, then LATs from X to Y and finally USD from Y to the United States, which creates pressure in country $X$ for the official price of the dollar $\left(\mathrm{O}_{\mathrm{X}}\right)$ to be reduced and in country $\mathrm{Y}$ for the official price of the dollar $\left(\mathrm{O}_{\mathrm{Y}}\right)$ to increase, consequently decreasing $\mathrm{PPPX}$ and increasing $\mathrm{PPP}_{\mathrm{Y}}$ (shown using black arrows). Alternatively, we could have that $\mathrm{PPP}_{\mathrm{X}} / \mathrm{PPP}_{\mathrm{Y}}<1\left(\mathrm{PPP}_{\mathrm{Y}}>\right.$ $P P P_{X}$ ). In this case (illustrated in Figure 5) instead of country $X$ we have $Y$ and instead of country $Y$ we have $X$, but it is the same situation as the one shown in Figure 4. The black arrow shows what speculative capital movements would tend to do to the PPPs of Y and X.

Equation (12) is the basic model for the implementation of LAT monetary policy and it is the basic contribution of this paper to economic knowledge of how defining a currency such as the LAT in the way in which it is portrayed in this paper could work.

Figure 4. The basic flows of capital in a LAT-based Latin-American Union within and outside of the Latin-American Union when $P_{P P}>P_{X P P_{Y}}$.

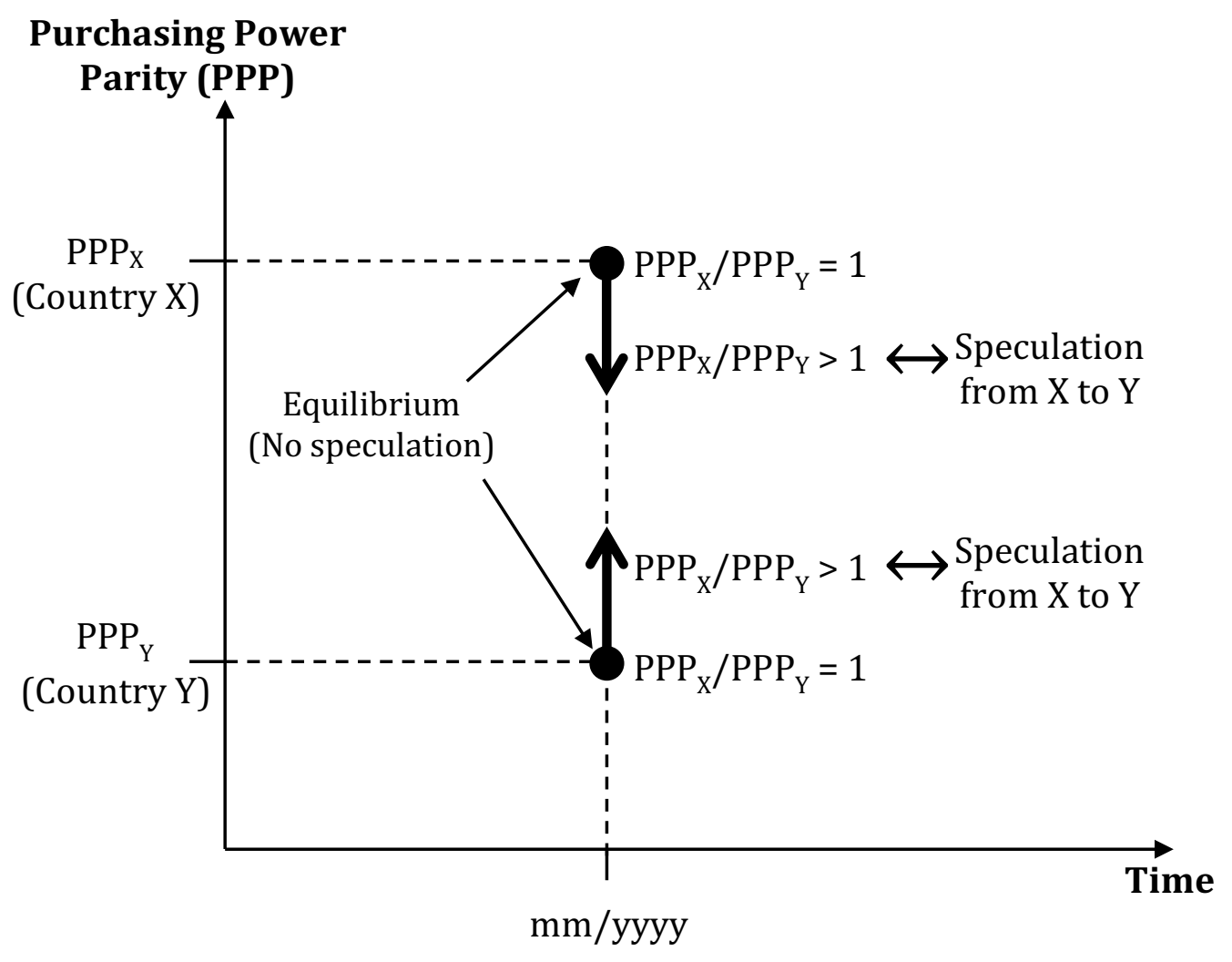

Figure 4 and Figure 5 describe the same situation, except that the role of $\mathrm{X}$ and $\mathrm{Y}$ are reversed. Notice that in Figure 4, $\mathrm{PPP}_{\mathrm{X}} / \mathrm{PPP}_{\mathrm{Y}}>1$ means that PPPX $>\mathrm{PPP}$. In Figure $5, \mathrm{PPPX}_{\mathrm{X}} / \mathrm{PPP}_{\mathrm{Y}}<1$ means that $P P_{Y}>P P P_{X}$. The basic model is still one and the same and it is given by equation (12). Thus, LAT monetary policy can only make PPPs approach to an intermediate value, which in theory should be close to the average PPP calculated in equation (21). 
Equation (12) and the diagrams in Figure 4 and Figure 5 constitute the basic macroeconomic model of the LAT. Notice that if we follow LAT monetary policy, the PPPs of all participating Latin-American Union members would tend to the same value. The advantage of the LAT is that it is given to Latin-American Union member governments for free, which should promote regional development. If the value of the LAT is calculated as $\mathrm{H}_{\mathrm{X}}$ according to equations (13) to (18), there would be a situation of equilibrium in all Latin-American Union member countries, no capital flows for speculation, and the LAT would be equally competitive than the USD for international transactions within the Latin-American Union.

Figure 5. The basic flows of capital in a LAT-based Latin-American Union within and outside of the Latin-American Union when $\operatorname{PPP}_{\mathrm{Y}}>\mathrm{PPP}_{\mathrm{X}}$.

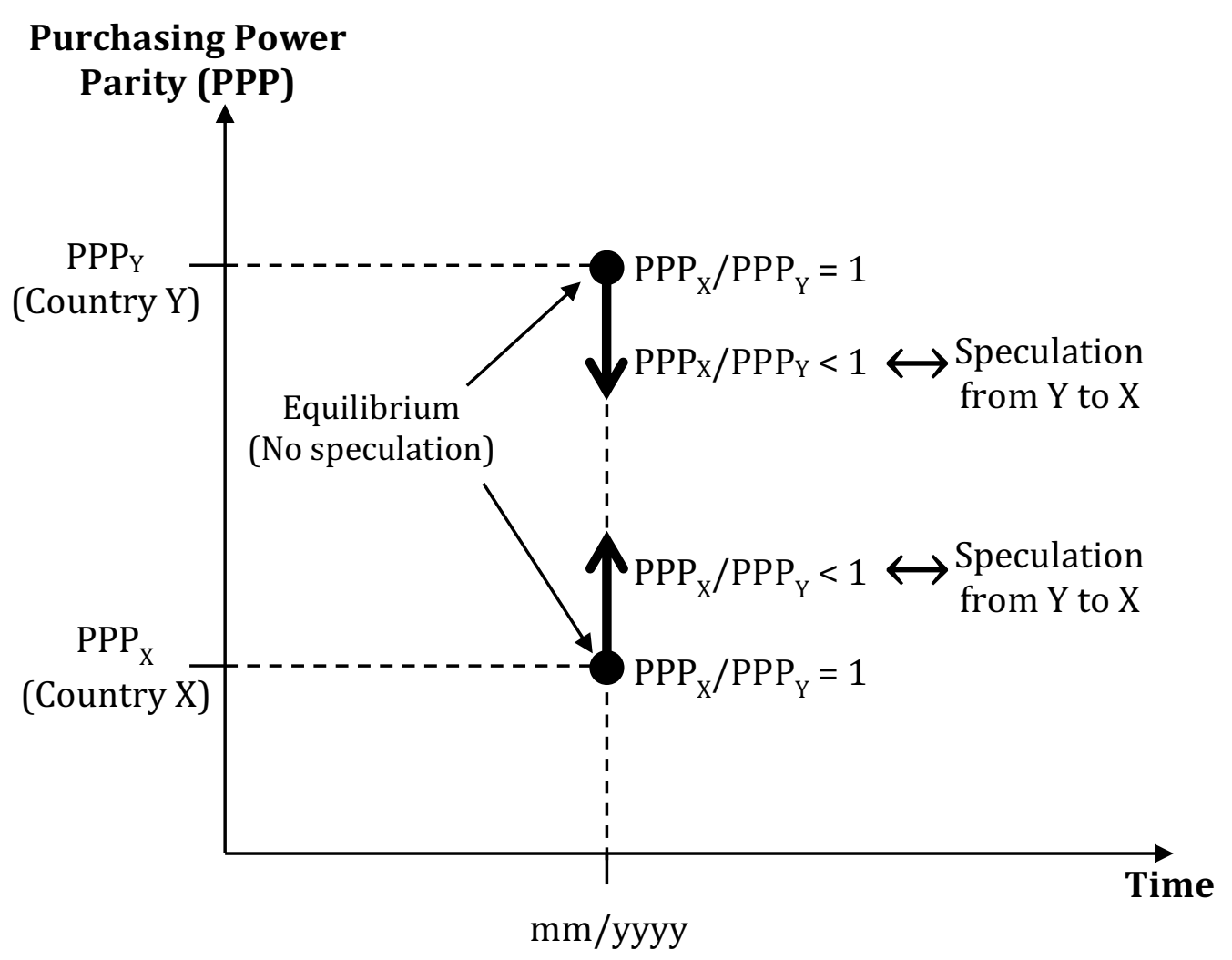

Is it possible to make sure all PPP values trend to one? Despite all of the effort from section 9.1, the proper LAT monetary policy so that the official value of the USD for country $\mathrm{X}\left(\mathrm{O}_{\mathrm{X}}\right)$ and the ideal value for such LAT ( $\mathrm{Lx}_{\mathrm{X}}$ ) to be the same (which is the same to say that $P P P_{X}=1$ ) is not so easy to achieve. Equation (18) indicates how to avoid speculation in the Latin-American Union. However, it does not say how to make sure the USD is not overvalued nor undervalued. The short answer to the question is: it is not guaranteed, since it depends on market fluctuations and other variables.

In order to understand, we need to analyze some examples. Consider the extreme case of October 2019, when we have the maximum trending PPP. We are going to use the approximated values for simplicity of calculations (avoiding digits after the decimal point). The countries considered to be members of the Latin-American Union are Argentina $(\mathrm{k}=1)$, Brazil $(\mathrm{k}=3)$ and Mexico $(\mathrm{k}=14)$. We have $\mathrm{P}_{0}=\$ 5$ USD/Big Mac, $\mathrm{P}_{1}=\$ 75$ ARS $/$ Big Mac, so that $\mathrm{I}_{1}=$ (\$75 ARS/Big Mac) $/(\$ 5$ USD $/ \mathrm{Big} \mathrm{Mac})=\$ 15 \mathrm{ARS} / \mathrm{USD}$ and as a consequence, $\mathrm{L}_{1}=\$ 15$ ARS/LAT. Also, $\mathrm{O}_{1}=\$ 60 \mathrm{ARS} / \mathrm{USD}$, so that $\mathrm{PPP}_{1}=\mathrm{O}_{1} / \mathrm{I}_{1}=\mathrm{O}_{1} / \mathrm{L}_{1}=(\$ 60 \mathrm{ARS} / \mathrm{USD}) /(\$ 15$ ARS $/$ USD $)=(\$ 60 \mathrm{ARS} / \mathrm{USD}) /(\$ 15 \mathrm{ARS} / \mathrm{LAT})=4$. Furthermore, $\mathrm{P}_{3}=\$ 15 \mathrm{BRL} / \mathrm{Big}$ Mac, so that $\mathrm{I}_{3}=(\$ 15 \mathrm{BRL} / \mathrm{Big} \mathrm{Mac}) /(\$ 5 \mathrm{USD} / \mathrm{Big} \mathrm{Mac})=\$ 3 \mathrm{BRL} / \mathrm{USD}$ and $\mathrm{L}_{3}=\$ 3 \mathrm{BRL} / \mathrm{LAT}$. Additionally, 
$\mathrm{O}_{3}=\$ 4 \mathrm{BRL} / \mathrm{USD}$. Thus, $\mathrm{PPP}_{3}=\mathrm{O}_{3} / \mathrm{I}_{3}=\mathrm{O}_{3} / \mathrm{L}_{3}=(\$ 4 \mathrm{BRL} / \mathrm{USD}) /(\$ 3 \mathrm{BRL} / \mathrm{USD})=(\$ 4$ $\mathrm{BRL} / \mathrm{USD}) /(\$ 3 \mathrm{BRL} / \mathrm{LAT})=1.3333$. Finally, there is $\mathrm{P}_{14}=\$ 50 \mathrm{MXN} / \mathrm{Big} \mathrm{Mac}$, so that $\mathrm{I}_{14}=(\$ 50$ MXN/Big Mac) $/(\$$ USD $/$ Big Mac $)=\$ 10 \mathrm{MXN} /$ USD and $\mathrm{L}_{14}=\$ 10 \mathrm{MXN} / \mathrm{LAT}$. There is also $\mathrm{O}_{14}=$ $\$ 20 \mathrm{MXN} / \mathrm{USD}$, so $\mathrm{PPP}_{14}=\mathrm{O}_{14} / \mathrm{I}_{14}=\mathrm{O}_{14} / \mathrm{L}_{14}=/(20 \mathrm{MXN} / \mathrm{USD}) /(\$ 10 \mathrm{MXN} / \mathrm{USD})=(20$ MXN/USD $) /(\$ 10 \mathrm{MXN} / \mathrm{LAT})=2$.

But the prices of the LAT should not be determined according to the value the USD should have, but rather on making sure there is no speculation, which would generate severe capital flows that could reckon economic systems. The minimum PPP is for $\mathrm{Z}=3$ (Brazil). Thus, according to equation (18), $\mathrm{H}_{1}=\mathrm{O}_{1} \times \mathrm{L}_{3} / \mathrm{O}_{3}=(\$ 60 \mathrm{ARS} / \mathrm{USD}) \times(\$ 3 \mathrm{BRL} / \mathrm{LAT}) /(\$ 4 \mathrm{BRL} / \mathrm{USD})=$ $\$ 45 \mathrm{BRL} / \mathrm{LAT}$. Notice that $\mathrm{O}_{1}>\mathrm{H}_{1}>\mathrm{L}_{1} . \mathrm{H}_{1}$ is the starting point for the value of the LAT. As a measure of LAT monetary policy, we should gradually reduce $\mathrm{H}_{1}$ so that the speculative capital movements reduce the official value of the USD in Argentina (reducing $\mathrm{O}_{1}$ ) and increase it in Brazil (increasing $\mathrm{O}_{3}$ ), trending both PPPs to the same value, so that the new $\mathrm{O}_{1}$ trends to a new value for $\mathrm{L}_{1}$ and the new value for $\mathrm{O}_{3}$ trends to a new value for $\mathrm{L}_{3}$. We could set $\mathrm{H}_{1}=\$ 40$ ARS/LAT, then to \$35 ARS/LAT, for example, and so on, until an equilibrium has been found between the PPP of Argentina and that of Brazil.

What about Mexico? At the same time we are doing the above for Argentina, we could operate on Mexico. We have $\mathrm{H}_{14}=\mathrm{O}_{14} \times \mathrm{L}_{3} / \mathrm{O}_{3}=(\$ 20 \mathrm{MXN} / \mathrm{USD}) \times(\$ 3 \mathrm{BRL} / \mathrm{LAT}) /(\$ 4 \mathrm{BRL} / \mathrm{USD})=\$ 15$ MXN/LAT. Once again, notice that $\mathrm{O}_{14}>\mathrm{H}_{14}>\mathrm{L}_{14}$. The value for the LAT is Mexico is initially $\mathrm{H}_{14}$ $=\$ 15 \mathrm{MXN} / \mathrm{LAT}$, but we could gradually decrease it (as a measure of LAT monetary policy) to $\$ 14 \mathrm{MXN} / \mathrm{LAT}$ and then to $\$ 13 \mathrm{MXN} / \mathrm{LAT}$, and so on, until the speculative movements trend to make all PPPs the same $\left(\mathrm{PPP}_{1}=\mathrm{PPP}_{14}=\mathrm{PPP}_{3}\right)$.

Let us now consider a more difficult example. What happens if the values for the PPP of one or more countries is less than one? The minimum trending PPP is 0.93 and it occurs on June 2008. For $\mathrm{t}=$ June 2008, we have a series of values that are much closer to the real ones this time (up to one decimal point), since it makes no much sense to round them up for simplicity of calculations. So, let us proceed with the calculations.

The same countries are considered: Argentina $(\mathrm{k}=1)$, Brazil $(\mathrm{k}=3)$ and Mexico $(\mathrm{k}=14) . \mathrm{P}_{0}=$ $\$ 3.5$ USD/Big Mac. $\mathrm{P}_{1}=\$ 11 \mathrm{ARS} / \mathrm{Big} \mathrm{Mac}, \mathrm{P}_{3}=\$ 7.5 \mathrm{BRL} /$ Big Mac, $\mathrm{P}_{14}=\$ 32 \mathrm{MXN} / \mathrm{Big}$ Mac, $0_{1}=$ $\$ 3 \mathrm{ARS} / \mathrm{USD}, \mathrm{O}_{3}=\$ 1.6 \mathrm{BRL} / \mathrm{USD}, \mathrm{O}_{14}=\$ 10 \mathrm{MXN} / \mathrm{USD}$. Thus, $\mathrm{I}_{1}=\mathrm{L}_{1}=(\$ 11 \mathrm{ARS} / \mathrm{Big} \mathrm{Mac}) /(\$ 3.5$ USD $/$ Big Mac $)=\$ 3.1$ ARS/USD $=\$ 3.1 \mathrm{ARS} /$ LAT. Also, $\mathrm{I}_{3}=\mathrm{L}_{3}=(\$ 7.5 \mathrm{BRL} / \mathrm{Big} \mathrm{Mac}) /(\$ 3.5$ USD $/$ Big Mac $)=\$ 2.1 \mathrm{BRL} / \mathrm{USD}=\$ 2.1 \mathrm{BRL} / \mathrm{LAT}$. Finally, $\mathrm{I}_{14}=\mathrm{L}_{14}=(\$ 32 \mathrm{MXN} / \mathrm{Big} \mathrm{Mac}) /(\$ 3.5$ USD/Big Mac $)=\$ 9.1 \mathrm{MXN} / \mathrm{USD}=\$ 9.1 \mathrm{MXN} / \mathrm{LAT}$. Consequently, $\mathrm{PPP}_{1}=(\$ 3$ ARS/USD $) /(\$ 3.1$ $\mathrm{ARS} / \mathrm{USD})=0.97, \mathrm{PPP}_{3}=(\$ 1.6 \mathrm{BRL} / \mathrm{USD}) /(\$ 2.1 \mathrm{BRL} / \mathrm{USD})=0.76$, and $\mathrm{PPP}_{14}=(\$ 10$ $\mathrm{MXN} / \mathrm{USD}) /(\$ 9.1 \mathrm{MXN} / \mathrm{USD})=1.10$. The lowest PPP is for Brazil $(\mathrm{k}=3)$, so that $\mathrm{Z}=3$. For equilibrium conditions, we have $\mathrm{H}_{1}=\mathrm{O}_{1} \times \mathrm{L}_{3} / \mathrm{O}_{3}=(\$ 3 \mathrm{ARS} / \mathrm{USD}) \times(\$ 2.1 \mathrm{BRL} / \mathrm{LAT}) /(\$ 1.6$ $\mathrm{BRL} / \mathrm{USD})=\$ 3.9 \mathrm{ARS} / \mathrm{LAT}$, and $\mathrm{H}_{14}=\mathrm{O}_{14} \times \mathrm{L}_{3} / \mathrm{O}_{3}=(\$ 10 \mathrm{MXN} / \mathrm{USD}) \times(\$ 2.1 \mathrm{BRL} / \mathrm{LAT}) /(\$ 1.6$ $\mathrm{BRL} / \mathrm{USD})=\$ 13.1 \mathrm{MXN} / \mathrm{LAT}$. Notice that now $\mathrm{H}_{1}>\mathrm{L}_{1}$ and $\mathrm{H}_{14}>\mathrm{L}_{14}$. We could reduce the value of $\mathrm{H}_{14}$ from $\$ 13.1 \mathrm{MXN} / \mathrm{LAT}$ to $\$ 12.5 \mathrm{MXN} / \mathrm{LAT}$, for example, in order to reduce the official value of the USD in Mexico $\left(\mathrm{O}_{14}\right)$ while increasing the official value of the USD in Brazil $\left(\mathrm{O}_{3}\right)$ and thus creating speculation to reduce $\mathrm{PPP}_{14}$ and increase $\mathrm{PPP}_{3}$, respectively. Nevertheless, there is nothing reasonable to do using LAT monetary policy to increase $\mathrm{PPP}_{1}$. In any case, $\mathrm{PPP}_{1}$ (equal to 0.97 ) is already very close to 1 so that no action in this regard is probably the best course of action. One way to increase a PPP less than one is by devaluating the local currency, which has to do with the country's central bank monetary policy and not with LAT monetary policy. 
Clearly, it is necessary to enforce LAT price compliance. For that, it may be a good idea to use blockchain technology (Mehta, Agashe, \& Detroja, 2019; Narayanan, Bonneau, Felten, Miller, \& Goldfeder, 2016; Vigna \& Casey, 2016). The actual supervising and enforcing mechanisms are left for the case a real implementation of the ideas presented in this paper is required, although the model from equation (12) provides the required guidance. Notice that the LAT is by no means a cryptocurrency, just that using blockchain technology could be useful for transparency and supervising effort purposes.

\section{LIMITATION AND CONCLUSION}

The limitation of this paper is that feasibility calculations were not carried out for all twenty candidate Latin-American Union members. Nevertheless, the model presented in equation (12) is robust and comprehensive.

The conclusion, nevertheless, is that the LAT, as it is proposed to function, seems to be a good alternative for trade within Latin America. The creation of the Latin-American Central Bank (LACB) is necessary for LAT enforcement and organization, but also to make sure proper regional development policies are implemented. The LAT and the creation of the LACB trends to make commerce within Latin-American Union countries and the importation of goods and services into Latin-American Union members more important than exportation to the USA. Thus, a balance between the desire of Latin-American entrepreneurs to make a profit out of having the population of their countries not receiving as many goods and services as they could and the interest of speculators to use arbitrage for making a profit out of such asymmetric situation would be created.

The model presented in equation (12) is key to the proper management of the LAT for LatinAmerican Union members. Such model considers capital inflows and outflows for a potential Latin-American Union and how to achieve equilibrium and/or changing such equilibrium through the use of speculation capital movements within and outside of the Latin-American Union. The model from equation (12) presents the opportunity for the creation of a new tool of LAT monetary policy, and it further explores the issues of the right value for local currencies and trying to make sure the USD is not overvalued nor undervalued. The way in which the LAT is managed, by allowing the LACB to give free loans to local governments part of the LatinAmerican Union is certainly novel and, although such loans could create some inflationary pressures because the local currencies are exchanged for LATs, I believe it is worth in order to promote regional development and stability within all Latin-American Union members.

\section{References}

Arana, M. (2013). Bolivar: American Liberator. Simon \& Schuster.

Banco de México. (2019). Tipos de Cambio para Revalorización de Balance del Banco de México. (Foreign Exchange Rates for the U.S. Dollar.) Retrieved from:

https://www.banxico.org.mx/SieInternet/consultarDirectorioInternetAction.do?accion=consultarCuadro\&idCua $\underline{\mathrm{dro}=\mathrm{CF} 336 \& \text { sector }=6 \& \text { locale }=\mathrm{es}}$.

Brealey, R. A. \& Myers, S. C. (1991). Principles of Corporate Finance. McGraw-Hill.

Bushnell, D. (1970). The Liberator, Simón Bolívar. Alfred A. Knopf.

Copertari Isaacson, L. F. (2014). Evaluación Financiera de Proyectos. Editorial Umbral.

Crow, J. A. (1980). The Epic of Latin America. University of California Press.

Fischer, S., Dornbusch, R., \& Schmalensee, R. (1990). Economía. McGraw-Hill.

Friedman, M. (2006). The Optimum Quantity of Money. Transaction Publishers.

Greco, Jr., T. H. (2009). The End of Money and the Future of Civilization. Chelsea Green Publishing. 
Hallsmith, G. \& Lietaer, B. (2011). Creating Wealth: Growing Local Economies with Local Currencies. New Society Publishers.

Harvey, R. (2000). Liberators: Latin America's Struggle for Independence 1810-1830. The Overlook Press.

Holden, R. H. \& Zolov, E. (2000). Latin America and the United States: A Documentary History. Oxford University Press.

Knoema. (2020). World GDP Ranking 2015 - Data and Charts. Retrieved from: https://knoema.es/nwnfkne/world-gdp-ranking-2019-gdp-by-country-data-and-charts.

Krugman, P. R., Obstfeld, M., \& Melitz, M. J. (2018). International Economics: Theory and Policy. Pearson Education Limited.

Lietaer, B. \& Dunne, J. (2013). Rethinking Money: How New Currencies turn Scarcity into Prosperity. Berrett-Koehler Publishers.

Lietaer, B. (2001). The Future of Money: A new way to create wealth, work, and a wiser world. Random House Group Limited.

Mehta, N., Agashe, A., \& Detroja, P. (2019). Bubble or Revolution?: The Present and Future of Blockchain and Cryptocurrencies. Paravane Ventures.

Narayanan, A., Bonneau, J., Felten, E., Miller, A., \& Goldfeder, S. (2016). Bitcoin and Cryptocurrency Technologies. Princeton University Press.

Newnan, D. G. (1988). Análisis Económico en Ingeniería. McGraw-Hill.

The Big Mac Index Spreadsheet. (2019). Big Mac Index Spreadsheet. Retrieved from: http://bigmacindex.org/spreadsheet.

The Economist. (2019). The Big Mac index. Retrieved from: https://www.economist.com/news/2019/07/10/thebig-mac-index.

Vigna, P. \& Casey, M. J. (2016). The Age of Cryptocurrency: How Bitcoin and the Blockchain are Challenging the Global Economic Order. Picador.

Wonnacott, P. \& Wonnacott, R. (1982). Economía. McGraw-Hill. 